\title{
Preliminary Analysis of Nutritional Factors in Breast Cancer
}

\author{
Drupadi Dillon ${ }^{*}$, Susilowati Herman ${ }^{\dagger}$, Yoshiyuki Ohno ${ }^{\ddagger}$, Joedo Prihartono ${ }^{\S}$, Santoso Cornain Il, $\neq$, \\ Goi Sakamoto ${ }^{\pi}$, Muchlis Ramli ${ }^{* *}$, Setyawati Budiningsih ${ }_{* \neq}^{\S}$, Sadao Suzuki ${ }^{\ddagger}$, Idral Darwis ${ }^{* *}$, Esti Soetrisnoll, \\ Kenji Wakai $^{\ddagger}$, Gunawan Tjahjadi ${ }^{\prime l}$, Didid Tjindarbumi ${ }^{* *}$, Susumu Watanabe ${ }^{\dagger \dagger}$, Endang Sri Roostini ${ }^{l \mid}$
}

\begin{abstract}
Abstrak
Data epidemiologi dan eksperimental menunjukkan bahwa ada hubungan antara keganasan dan faktor gizi. Baik keganasan maupun faktor gizi merupakan bidang yang kompleks, oleh karena itu mempelajari hubungan antara keganasan dan faktor gizi tidaklah mudah. Pada umumnya telah diketahui, bahwa diperlukan waktu yang lama untuk suatu pertumbuhan ganas. Data gizi, terutama catatan tentang apa yang telah dimakan oleh seseorang untuk jangka waktu yang lama sulit didapat secara akurat. Tujuan dari penelitian ini adalah untuk mendapatkan cara yang cukup baik untuk dapat menjelaskan tentang adanya hubungan antara keganasan dan faktor gizi pada penderita kanker payu dara dengan menggunakan metode "Food Frequency Questionaire" untuk periode-periode tertentu dalam kehidupan penderita. Penelitian ini merupakan suatu penelitian "Case Control" yang dilakukan pada 20 triplets (1 kasus, berpasangan dengan 2 kontrol) penderita kanker payu dara yang berobat jalan di Rumah Sakit Mangunkusumo Jakarta. "Food frequency amount" dari empat waktu kehidupan yaitu sebelum dan sesudah menikah, lima dan sepuluh tahun sebelum diketahuinya penyakit dilakukan pada penderita dan mencakup 98 bahan makanan. Respons yang sama untuk 10 bahan makanan (10.2\%) diamati pada periode sebelum dan sesudah menikah, sedangkan $89.8 \%$ bahan makanan mendapat respons yang sama pada periode lima dan sepuluh tahun sebelum diketahuinya penyakit. Tidak terdapat jawaban untuk 19 bahan makanan dan respons cukup baik didapatkan untuk pertanyaan tentang tujuh cara memasak. Dapat disimpulkan bahwa waktu pernikahan merupakan saat yang baik dipakai sebagai patokan waktu untuk bertanya tentang pola makan, terutama bila menyangkut masa yang cukup panjang/lama. Sembilan belas bahan makanan yang tidak mendapat respons (karena sangat jarang dikonsumsi) akan dikeluarkan dari daftar pertanyaan "Food Frequency amount". Penelitian ini dilanjutkan dengan menggunakan pertanyaan yang telah disesuaikan dengan hasil sementara ini.
\end{abstract}

\begin{abstract}
Epidemiological and experimental data indicate that cancer could be linked to nutritional factors. Both nutrition and cancer are complex subjects, therefore to investigate the link between cancer and nutrition is not an easy task. It is generally believed that cancer needs a long time to develop. On the other hand, and accurate dietary records over a long period of time is difficult to obtain. The aim of this study is to find a method which is able to give a better estimate in elucidating a cancer-diet relationship in patients with breast cancer, using a modified food frequency questionaires for specific time periods. A total of twenty tiplets (one case, two matched controls) nutritional forms were done during a pilot case-control study on breast cancer in Cipto Mangunkumo Hospital, Jakarta. Using Food Frequency Amount (FFA) questionaire of 4 different periods: before and after marriage, five and ten years before disease occurence, $a$ total of 98 food items were covered. Identical responses to FFA between before and after marriage were found only among 10 food items $(10.2 \%)$, while $89.8 \%$ figure was obtained between the five and ten year periods. No responses to 19 food items by all 60 respondents but quite good response to seven different cooking preferences questionaires. It is concluded that time of marriage can be used as milestone in interviewing dietary pattern. Nineteen food items would be dropped out from the questionaire. The implementation of the definitive study is now in progress.
\end{abstract}

Keywords: dietary assessment, nutrients, breast cancer, care-control study

\footnotetext{
Department on Nutrition, Faculty of Medicine, University of Indonesia, Jakarta 10430, Indonesia

' Research and Development Center for Nutrition, Ministry of Health, Bogor, Indonesia

* Department of Preventive Medicine, Nagoya University, School of Medicine, Nagoya 466, Japan

$\S$ Department of Community Medicine, Faculty of Medicine, University of Indonesia, Jakarta, Indonesia

"Department of Anatomic Pathology, Faculty of Medicine, University of Indonesia, Jakarta 10430, Indonesia

"Department of Pathology, Cancer Institute, Tokyo 170, Japan

${ }^{* *}$ Department of Surgery, Faculty of Medicine, University of Indonesia, Jakarta 10430, Indonesia

tt Department of Surgery, Cancer Institute, Tokyo 170, Japan

${ }^{\ddagger}$ Research Center for Medical Science and Technology, Faculty of Medicine, University, Jakarta 10430, Indonesia
}

Epidemiological and experimental data estimate that about thirty five percent of all cancer deaths may be linked to nutritional factors.

The relationship between nutrition and cancer in particular to carcinogenesis has been reviewed ${ }^{1}$. Carcinogenesis is a multistep process that may take years to develop, and has yet to be properly understood. Nutrition or diet is concerned with any substances which are ingested during eating or drinking. In relation to cancer, diet may include carcinogens, contributing factors that could enhance any carcinogenic process considered as a risk factor, inhibitor of car- 
cinogenesis which is protective or factors which have effects on the immune response system that protects individuals from cancer. ${ }^{2,3}$

In breast cancer, both epidemiological and laboratory studies suggested that high fat diet increases the risk of breast cancer although various confounding variables might exist. ${ }^{1,3-6}$ An epidemiological study on breast cancer in Indonesia indicated that fatty food was one of the risk factors. ${ }^{7,8}$ On the other hand, some micronutrients such as $\beta$ carotene, selenium, vitamin $\mathrm{C}$ and vitamin $\mathrm{E}$ showed an inverse relationship in cancer incidence. Several studies also showed that diet high in fiber reduced the risk - this relation is evell stronger compared to the association of breast cancer with dietary fat intake. These substances in the diet are possibly markers of vegetable and fruit intake. ${ }^{5,9}$

It is generally believed that cancer needs a long time to develop; therefore diet-breast cancer connection is difficult to observe since it is extremely difficult to determine with any precision what people eat, especially over long periods of time.

Case control study has been substantially applied in Japan ${ }^{10}$ and the methodology allows further micro nutrient analysis. ${ }^{11}$

Dietary assesment as a tool to investigate what people eat has some weaknesses. An accurate record is far from easy to achieve, especially in the case of cancer, where there is a need to estimate over long periods.

A Food Frequency Questionaire is one method to test a diet association with disease.It is meant to asses the frequency with which certain food items are consumed during specific time periods and futhermore, it is possible to include quantitative means in the questionaire. ${ }^{12-14}$

The objectives of the study were as follows :

1. Which milestones in the women's life were most likely to be remembered in distinguishing the major changes of dietary pattern: the marriage or five and ten years before disease occurence?

2. What were the most appropriate food items to be covered?

3. Could we ask the respondents on their preferences in preparing their food?

\section{METHODS}

In a pilot case control study, subjects were recruited from an outpatient clinic at the by Dr. Cipto Mangunkusumo National Central General Hospital Jakarta. One new breast cancer patient was matched by age and socio economic class against two controls. Cases as well as controls came from different parts of Indonesia since it is a top referal hospital.

A Food Frequency Amount questionaire using a total of 98 food items most commonly found in the Indonesian diet was designed. Four different periods were clearly demarcated in the questionaire: before marriage, after marriage, five and ten years before disease occurence.

Additional information such as that on different cooking preparations was also recorded.

The interviews were performed by dieticians, using food models to help respondents in estimating the amount of food consumed.

\section{RESULTS}

A total of 20 new breast cancer patients and 40 controls were recruited within 6 month period.The mean age was 46 years for cases and 44 years for controls while the mean length of marriage was 28 years for cases and 27 years for controls.

Table 1 shows number of food groups with their respective food items.

Table 1. Number of Food Items According to Food Groups

\begin{tabular}{lc}
\hline Food Groups & Number of Food Items \\
\hline Fat sources & 14 \\
Carbohydrate sources & 13 \\
Protein sources & 19 \\
Vegetables & 26 \\
Fruits & 12 \\
Traditional Drinks & 5 \\
Traditional Snacks & 9 \\
\hline Total & 98 \\
\hline
\end{tabular}

Among the 98 food items included in the questionaires, 88 food items or $89.8 \%$ showed identical responses between five and ten years prior to the disease occurence, as shown in table 2.

Table 2. Response to Food Items According to Time Period.*

\begin{tabular}{lccr}
\hline Food group & $\begin{array}{c}\text { Similar } \\
\text { response }\end{array}$ & $\begin{array}{c}\text { Different } \\
\text { response }\end{array}$ & Total \\
\hline Fat sources & 13 & 1 & 14 \\
Carbohydrate sources & 12 & 1 & 13 \\
Protein sources & 16 & 3 & 19 \\
Vegetables & 25 & 1 & 26 \\
Fruits & 10 & 2 & 12 \\
Traditional Drinks & 4 & 1 & 5 \\
Traditional snack & 8 & 1 & 9 \\
\hline Total & 88 & 10 & 98 \\
\hline
\end{tabular}

* 5 and 10 years prior to disease occurence 
On the other hand, only 29 food items or $29.6 \%$ showed identical responses between pre and post marriage as shown in table 3 .

Table 3. Response to Food Items According to Marital Time**

\begin{tabular}{lccc}
\hline Food Group & $\begin{array}{c}\text { Similar } \\
\text { Response }\end{array}$ & $\begin{array}{c}\text { Different } \\
\text { Response }\end{array}$ & Total \\
\hline Fat sources & 9 & 5 & 14 \\
Carbohydrate & 5 & 8 & 13 \\
$\quad$ sources & 6 & 13 & 19 \\
Protein sources & 8 & 18 & 26 \\
Vegetables & 7 & 5 & 12 \\
Fruits & 1 & 4 & 5 \\
Traditional drinks & 3 & 6 & 9 \\
Traditional snacks & 39 & 60 & 98 \\
\hline Total & & & \\
\hline
\end{tabular}

** pre and post marriage

It is important to know that out of those 29 food items which showed identical response, 19 of them were due to no-response effect. No response were also given to 19 food items for the time period ( 5 and 10 years prior to disease occurance).

Among fat sources included in the questionairs, coconut milk, beef fat and internal organs were consumed more by cases compared to the controls, with similar frequency during pre and post marriage.

Similar responses were also given for spinach, swamp cabbage, cassava leaves, carrots and Chinese cabbage.

All cases and controls gave good responses to food preparation preference.

\section{DISCUSSION}

Indonesian archipelago consists of many different ethnics with different food habits and preferences. It is not uncommon to have inter marriages between these ethnic groups. Many young couples move to the other area which has different food habits (sometimes due to food availability) from their original area, leading to change in their food habits.

Along the life cycle, marriage is a very important event. Most women participating in the study were able to differentiate their food habits between adolescence and marriage; especially when they married to a person from different area, different socio economic level or they moved to another area after marriage.
Cancer needs a long time to develop, sometimes 20 years. The mean age of the respondents was 45 years (46 for cases and 44 controls) while the mean length of marriage was 27 ( 28 for cases and 27 for controls) years: this means that the food frequency questionaire covering the pre marriage as well as the post marriage reflected their food habits around 20 years ago. Studies on diet - cancer links have been done by a number of investigators. Some cohort studies were done for 20 years, ${ }^{5} 16$ years ${ }^{9}$ and 8 years, ${ }^{15}$ but previous case control studies only went as far as two year recall.

There was no response to 19 food items for all four different periods; those were for food items not as commonly consumed by Indonesians such as pork fat, corn oil, peanut oil, soy oil, pork, birds, watercress, leeks etc. Identical responses to 88 food items by the five and ten years prior to disease occurence might be due to the difficulties in differenciating between those two periods. There is a strong possibility that the answer reflected their current food habits. ${ }^{16}$ The 29 identical responses by the pre and post marriage actually only included ten identical responses because the 19 food items were actually due to "no-response" effect.

Coconut milk, beef fat and internal organs contain about $40 \%$ fat. These food items were consumed more by the cases. This is in accordance with the findings of previous investigators.

Spinach, swamp cabbage, cassava leaves, carrots as well as chinese cabbage are good sources of $\beta$ carotene. This food items were consumed more by the cases compared to controls. Whether our data were in variance with other findings, needs clarifying by evaluation on larger samples.

\section{CONCLUSION}

Time of marriage can be used as milestone in interviewing dietary pattern using a food frequency amount questionaire. Nineteen food items would be dropped out from the questionaire, while cooking preferences can still be put in the questionaire.

\section{Acknowledgments}

The authors are grateful to the nurses, Ms. Ros and Ms. Emi, and the nutritionists, Ms. Hastuti Djalil, Liliek $A R$, and Meuthia KS for excellent care of breast cancer cases and controls and collection of epidemiological and nutritional data by interviews using standard questionaire. This work was supported by the Ministry of 
Education and Culture, Japan, Grants No. 01042007 and 04042013; and was partly supported by the Indonesian Cancer Foundation. This collaborative study was a part of Special Cancer research Project in Monbusho International Scientific Research Program, with the approval of the Dean, Faculty of Medicine, University of Indonesia, No. 4383/PT02.H4.FK/E/88.

\section{REFERENCES}

1. Linder MC. Nutrition and cancer prevention. In: Linder MC, editor. Nutritional biochemistry and metabolism, with clinical applications. 3rd ed. London: Prentice-Hall International Inc., 1991:475-505.

2. KJine, K. Breast Cancer:The diet cancer connection. Nutrition Today 1986;1:11-6.

3. Clifford C, Kramer B. Diet as risk and therapy for cancer. Med Clini of North America 1993;77:725-28.

4. Van't Veer P, Kok J , Brants HAM. Dietary fat and the risk of breast cancer. Int'l J Epid.1990;19:15-7.

5. Knekt P, Albanes D, Seppanen R. Dietary fat and risk of breast cancer. J Clin Nutr 1990;52:903-8.

6. Carrol K. Dietary fat and breast cancer. Nutrition Update $1985 ; 2: 30-47$

7. Budiningsih S, Ohno Y, Prihartono M, Ramli M, Wakai K, Cornain S, et al. Epidemiological Analysis of Risk Factors for Breast Cancer. In Indonesian females. Med J Indones $1995 ; 4: 163-8$

8. Suzuki S, Prihartono J, Ohno Y, Budiningsih S, Wakai K, Cornain $S$, et al. Epidemiologic risk factors for breast cancer related menopausal status iñ Indonesia. Med J Indon 1995; 4:169-76.

9. Hirayama T. A large scale cohort study on cancer risk by diet - with special reference to risk reducing effects of green-yellow vegetable consumption. In: Hayashi Y, Nagao T, Sugimura $T$ et al, editors. Diet, Nutrition and cancer. Tokyo: Japan Sci Soc Press, 1986;41-53.

10. Ohno Y. Methodology and evaluation of dietary factors in Japan. In: Mettline CJ and Aokj K, editors. REcent Progres and Research on Nutrition and Cancer. New York: WileyLiss Inc. 1990:11-20.

11. Ohno Y, Yoshida O, Oishi K, Okada K, Yanabe H, Schroeder FH. Dietary $\beta$-carosene and cancer of the prostate: A case-control study in Kyoto, Japan. Cancer Res 1988;48:1331-6.

12. Bingham $S$, Nelson M, Paul EA, Haraldsdottir J, Lokan EB, van Staveren WA. Methods for data collection at individual level. In: Cameron E, van Staveren WA, editors. Manual on methodology for food consumption studies. New York: Oxford University Press, 1988:88-96

13. Herbert, Miller R. Methodologic considerations for investigating the diet-cancer link . Am J Clin Nutr 1988;47: 1068-77.

14. Abramson JH, Slome C, Kasovsky. Food frequency interview as an epidemiological tool. Am J of P H 1963; 53:1093100 .

15. Willet, Hunter J, Stampfer J, et al. Dietary fat and fiber in relation to risk of breast cancer. JAMA 1992;268:2037-43.

16. Rohan TE, Record SJ, Cook MG. Repeatibility of estimates of nutrient and energy intake: The quantitative food frequency approach. Nutr Res 1987;7:125-37. 